UDC 798.2(450)

\title{
ITALIAN HORSE RIDING SCHOOL
}

\author{
Zbigniew Wójcik ${ }^{1}$ \\ ${ }^{1}$ Departament of Turism and Recreation, University of Warmia \& Mazury in Olsztyn, Poland, zbigniew-wojcik@o2.pl
}

https://doi.org/10.29038/2220-7481-2020-01-60-63

\begin{abstract}
s
The system solutions in the field of horse riding technique appeared for the first time in Italy in the 16th century, but at the same time equestrian academies also functioned in other countries, e.g. Austria, France, Germany and Russia. They formed the horse riding system which was based on such movements that horse never performs in its natural habitat. Therefore, according to the methodology research, applicable in historical and pedagogical sciences, an attempt was made to determine stages of the Art of Horsemanship on the European continent. In the research process, it was established that the horse riding style that had been being practiced for several centuries, was not changed until the late 19th century. The revolutionary changes, based on years of observation and experience, were made by Captain Federico Caprilli of the Military Equestrian School in Pinerolo (Italy). The result of his observations accepeted in 1906 was an innovative horse riding system called natural. A great numer of officers from 22 countries were coming to Italy at that time to learn the new system. As it was very practical, it became quickly adapted by equestrian sport.
\end{abstract}

Key words: horse riding technique, horse, academy, natural system.

Збігнсв Войчік. Італійська школа верхової їзди. Системні дослідження в галузі техніки верхової їди вперше з'явилися в Італії в XVI столітті. Проте в той же час кінні академії функціонували також в інших країнах, наприклад Австрії, Франції, Німеччині та Росії. Вони розробили таку техніку верхової їзди, яка грунтувалася на pyхах, які кінь ніколи не здійснював у природному середовищі свого існування. Тому, відповідно до методологічних досліджень у історичних та педагогічних науках, зроблено спробу визначити етапи розвитку мистецтва конярства на європейському континенті. У процесі дослідження встановлено, що стиль верхової їди, який практикували впродовж декількох століть, не змінювався до кінця XIX століття. Революційні зміни в цій галузі як результат багаторічних спостереженнь та досвіду здійснив капітан Військової кінної школи в Пінероло (Італія) Федеріко Капріллі. Результатом його спостережень у 1906 році стала розробка інноваційної системи технік верхової їзди під назвою «природна». Багато офіцерів більш як із 22 країн світу приїздили до Італії для навчання новітньої техніки верхової їзди. 3 огляду на ії практичність, така методика почала швидко застосовуватися в кінному спорті.

Ключові слова: техніка верхової їди, кінь, академія, природна система.

Збигнев Войчик. Итальянская школа верховой езды. Системные исследования в области техники верховой езды впервые появились в Италии в XVI веке. Однако, в то же время конные академии функционировали также в других странах, например Австрии, Франции, Германии и России. Они разработали такую технику верховой езды, которая основывалась на движениях, которые лошадь никогда не совершала в естественной среде своего существования. Поэтому, согласно методологических исследований в исторических и педагогических науках, была предпринята попытка определить этапы развития искусства коневодства на европейском континенте. В ходе исследования установлено, что стиль верховой езды, который практиковали в течение нескольких веков, не менялся до конца XIX века. Революционные изменения в этой области как результат многолетнего наблюдения и опыта совершил капитан Военной конной школы в Пинероло (Италия) Федерико Каприлли. Результатом его наблюдений в 1906 году стала разработка инновационной системы техник верховой езды под названием «естественная». Многие офицеры более чем из 22 стран мира приезжали в Италию для обучения новой техники верховой езды. Учитывая ее практичность, такая методика быстро стала применяться в конном спорте.

Ключевые слова: техника верховой езды, лошадь, академия, естественная система.

Introduction. The aim of the initiated research was to determine the stages of shaping the art of horse riding in Europe. On the other hand, the inspiration was the fact that there was no broader study on this subject in Polish scientific journals. Therefore, the study was based on the hypothesis that the innovative trends appeared in the Renaissance period and along with a strong trend of humanism including particular countries. For this reason, the following research questions were formulated:

1. What criteria infuenced directly on the development of horse riding technique?

2. In what time periods was it composed in a coherent conception?

3. When and where was the up-to-day current system born? 
In the research process the following methods of sciences were applied:

a) historical (direct, indirect, comparative);

b) pedagogic (documents analysis).

The Beginnings of the Art of Horse Riding. The beginnings of the Art of horse riding ought to be found in the middle of the sixteenth century $[6 ; 10]$. Then, as a result of technical inventions, changes were introduced in mounted cavalry arms and knight's gear that were successively replaced with firearms. It is worth mentioning in this context that the keystone of a strong state was horseback army at that time and every knight possessed one heavily and two lightly-armed horsemen [1]. The further development was closely bound up with conquests and warfare and the changes in horse riding manners ensuing mainly the evolution of tactics of warfare [8]. The end of the sabre and lance era coincided with the beginning of the age of Enlightenment relating to the strong trend of humanism. It provided mankind with new possibilities and challenges.

Considering the above mentioned reasons, the structured horse breeding farms on the west of Europe, especially in Italy, gained much bigger significance [3]. Italy was the place that gave rise to the new idea that was spread throughout the neighbouring nations. The humanists from Milan, Rome and Florence are reckoned to be creators of the new concepts that resulted in a wide response throughout the whole Europe. Their visionary ideas also found their reflection in the development of the knowledge of horses - hippology that deals with horse breeding, its improvement, as well as the discourse of artistic horse riding academy. During that time, Federico Grisone's horse riding academy became particularly famous [3]. It is a nobleman Grisone of Naples who, as the author of a treaty on dressage Gli ordini di cavalcare (1550), is considered to be the father of classical equitation $[7 ; 12]$ and the precursor of modern horse riding manege school. Whereas Italy, due to the fact that the first academy was established there in the sixteenth century, it is considered to be the cradle of contemporary art of horse riding. In the spirit of the Italian humanism, horse-riding centers began to evolve in other countries as well. In the past centuries, the study of horsemanship played also a substantial role in bringing up youth. A Czech educator, a philosopher and Protestant thinker, Jan Amos Komeński (1592-1670), was among the first who noticed the advantages of such classes by launching teaching it in his schools.

Nevertheless, it is essential to underline in this point that the art of horseback riding in Europe has been developing for over a number of centuries and characterized by many varieties. Imported but also captured fast horses from the East were its complement. Existing to the present day, the Spanish Royal Riding School in Vienna powerfully impressed upon the horse riding evolution process. The school was established in the sixteenth century initiated by an Austrian archduke Charles of Lipiza. The achievements made by its students were widely known on the European continent. The queens, princes and high born men who were studying there horse riding basics induced additional glamour to the school [4]. Established in 1775, the French Cavalry School of Saumur brought equally a big contribution to the horsemanship progress. Another well-known, but much later established institute was the German Cavalry School in Hannover. It is worth mentioning that among its graduates was Claus Schenk von Stauffenberg, the author of an assassination attempt on Adolf Hitler. Equally interesting seems to be the fact that breeding of Trakehner horse developed well on the Polish territory of Prussian annexation. In 1790, there were as many as 530,000 horses in Prussia, and the studs located there belonged to the main suppliers of these animals for the army. Napoleon's army during the conquest of Europe took over over 75,000 mounts at that time. Preparing for war with Russia, the Emperor commandeered in 1812 additionally nearly 104,000 horses. They were used mainly for horseback riding.

The substantial role in shaping the horse riding system was also played by functioning since 1877 the Russian horse riding school in Saint Petersburg and the Austrian Milibar Reitlehrer Institute in Vienna (1875). Horse riding classical-manege schools dominated in all the outposts. The real and radical change, however, occurred in the turn of the nineteen and twentieth century at the Italian Cavalry School at Pinerolo, a small country town located about 30 kilometers west of Turin.

\section{The System of Horse Riding}

As it was mentioned above, Italy has already become the cradle of the talented horse riding reformers in the sixteenth century and the elaborated concept together with spiritual humanism infiltrated to the neighbouring countries. The appriopriate system, however, was formed much later, established in 1824 by the king of Sardinia, Charles Felice- above mentioned-at the Italian Cavalry School in Pinerolo. Worth noticing is the fact that the cavalry school in Pinerolo in its beginnings did not distinguish itself in this matter. Hence, the level of horse riding training was not high. The results of this situation were noticed by military authorities. The Italian army failure in the Battle of Custoza (1866) disclosed the hitherto system deficiencies. While searching for the means to counteract this stagnation, the school commander colonel Lauzavecchia di Burii, having no competent candidates among Italian officers, employed a distinguishing Austrian horseman, lieutenant Casare Paderni on a civil law contract [5]. Influenced by horse riding manege school, Paderni was at the same time 
open to off-road horse riding as well as par force hunting (a type of horse hunting with a pack of dogs). Therefore, he opened in Tor di Quito a branch of the school in the interest of increasing the riders' skills in the off-road horse riding. The post was situated a few kilometers north of Rome, where the second stage of learning (after Pinerolo) was implemented. Here, according to R.Urban, the riders and horses were developing a quick sense of direction and making decisions, will to risk, courage, character, territory cognition and adjusting to its requirements. It harmonized with an Italian cavalry motto: sempre avanti (it means 'Ever Forward' and 'Always Ahead'). Being responsible for 25 years of horse riding training, Paderni personally conducted many instructor courses. Additionally, he educated various horsemanship masters from whom the most talented one proved to be the later captain Federico Caprilli [5]. In 1980, he took up the education in the cavalry academy. As a lieutenant, he noticed that mounting a horse and the principles of manege horse riding were in a striking contrast to off-road riding, especially in overcoming obstacles [7]. On the basis of a countless number of experiments, tests and long-term observations, he searched for optimum mounting position and the principles of a rider's proper position correspoding to natural horse movements.

In the traditional horse riding system provoking natural movements is not enough, it also requires many different movements as well, even these ones that horses living in its natural habitat never perform. According to many famous experts, a horse, being trained and ridden too long in the manege system, becomes an artificial and unnatural show mount. 'A horse that always moves 'at attention', gets tired very quickly and is less free in its movements' [2]. Such situation is clearly visible on uneven, and covered with obstacles terrain. Then, the horse possessing its natural, free posture can help itself with keeping balance as well as adjusting and shaping up properly to an obstacle or area. F. Caprilli was the first who spotted such reliance. For many years he had been observing horses' behaviour under the rider in many different situations, and paid particular attention to horses moving in its natural environment - open area. In 1901, as a lieutenant, he published in military magazine 'Rivieta di Cavaleria' a sole article entitled 'Principia di equitazionedel tenente Federico Caprilli' [5]. There, he included his conclusions and remarks regarding carried out studies and observations that helped him dominate over the world top competitive riders on the international equestrian competitions in Turin (1902) [10]. Captain Caprilli outclassed his opponents by overcoming a 208-centimeter high obstacle and another 660 centimeters wide one. Adopted in 1906, in the Italian Cavalry Schools, the innovative horse riding system called the natural one was the result of his achievements and experiences. It has been specific revolution in the hitherto horsemanship in the world since it set the foundation for the modern forward riding system. Its basic principles, comprehensible for a rider and natural for the horse, were as following:

1. Not to use at the same time two different riding aids, that is working with calves not hands (reins) at the opposite.

2. Demanding from the horse direction, using one hand (rein), do not work like in manege system, with the opposite hand at the same time.

3. Demand from the horse only natural, simple movements it executes without a rider.

4. Demand from the horse movements by leaving it free of performing it in such a way that would be the easiest and most convenient for it without any form of interference.

5. Always leave the horse at ease so that it can catch on the most uncomplicated an appropriate posture i.e. natural'[2].

All in all, the general principle of Caprilli's system was to allow the horse the greatest freedom (of its neck, trunk, head) by staying, at the same time, in contact with it using hands, reins as well as the seat and calves. The rider was also supposed to adjust their position to the horse's movements in such a way so as not to interfere in its inborn rhythm. Another rule was to mount it mainly outdoors, in the terrain. The cavalry school good equipment and training base highly contributed to this revealing conception. The school in Pinerolo possesed three riding halls: two slightly older and one- named after Caprilli - with dimensions of 70x20 meters, equipped with very modern, considering those times, facilities. In the barrack complex there also was a jumping arena (campo d'Ostacoli) of 1200 metres in circumference with deliberately built-up obstacles. The training base was completed by official competitive horse riding track and another, called a training one. According to the connoisseurs of this subject, however, the biggest role in equestrian training was assigned to situated about $4500 \mathrm{~m}$ from the town, the Galoppatoio generale Berta terrain [7].

This revolutionary school brought generally awaited results and made its founder the chief of horse riding in a Cavalry Training Centre in Pinerolo, in 1906. On the threshold of the twentieth century, Caprilli's revealing system conquered nearly all horse riding schools existing at that time. The main idea was that the rider had to adjust to the horse, what was contrary to the manege system, where the horse had to submit to a rider. In such circumstances the rider assumed jumping position on shortened from the length stirrups instead of the deep riding position of manege school [7]. Continuous series of Italian competitors' triumphs on 
international equestrian contests were noticed by many riders around the world. Therefore, during the years 1920-1930, the rest of the riding community from 22 countries came to learn from them [2;11]. At that time, the Olympians from Stockholm stood out among the Polish officers: Second Lieutenant Karol Rómmel and Lt. Sergiusz Zahorski. The above mentioned system compelled the necessity of elaborating a new saddle, the so-called Italian one. Over the time it became, after the English design, another basic model eagerly used in sports rivalry. The future, however, showed that the natural system, although revelational and practical one, did not pass an exam in all the equestrian disciplines. Such incoherence was also spotted by the Polish instructors after the First World War. It is also worth mentioning here about English traditions since in that country mounting the horse was practised in a different way than elsewhere in Europe. For many years, the English favourite styles were hunt riding system, par force hunting and horse races. Hence, big numbers of packs of hounds were kept on the island. It was a peculiar system of horse riding that originated from national traditions and was deeply rooted in them. It is necessary to underline that on the basis of these customs in the decadent period of the eighteenth century, a special type of English saddle was created, and then used for quite a long time in equestrian events [10]. The riding system of the British was to some extend similar to a modern Caprilli's system, and that is why these continental standards arrived later. Horsemanship in the past centuries developed mainly in military surroundings. The horse was then perceived in a category of effective means of transport. For that reason, in the nineteenth century, the Germans noticed a connection between horse-breeding and sport that strongly correlated with cavalry training. Even officers in East Prussia were obliged to participate in horse and hunt races [3]. Not accidentally, equestrian sport has its origins in the army. After all, it was a perfect way to stop soldier's monotony. Elaborated basics of a natural riding school, in force up till today, is the merit of Italian Captain Federico Caprilli. The Poles also applied these methods skillfully, that was proved by Adam Królikiewicz in the Olympic Games in Paris (1924). His success had a tremendous importance while constructing assumptions of the Polish riding school [12].

Conclusions. The relationship between the horse and the man impressed upon on the military art. Evolving tactics of waging wars remained in a close connection with horse riding technique. Introduced in the sixteenth century in the knighthood ranks firearms, drove out lances and sabres consecutively extorting changes in horse riding technique. Its concepts, entitled then as manege school were elaborated during the Renaissance period in Italy. A new method of mounting a horse quickly spread over the European continent. This, in consequence, led to establishing cavalry schools where the students were trained new methods of a horseback riding. In the past centuries, a couple of classical riding school varieties were elaborated. However, at the turn of the nineteen and twentieth century, its proper system called natural one was compiled by the Italian Cavalry School at Pinerolo graduate, Captain Federico Caprilli. Masses of 22 officers from different countries arrived to Italy just to study it. The natural system of forward riding, a very practical one, was very quickly adopted by the supporters of developing at that time equestrian sports. Nowadays, it has been widely practiced in modern horsemanship.

\section{References}

\section{Publications}

1. Kamzolov, G. W. (2002). The history of the Trakehners. Chevalier.

2. Królikiewicz, A. (1958). Rider and the horse in the terrain and in the jump. Sport and Tourism.

3. Osterloff, W. K. (1976). The history of sport. Our Bookshop.

4. Pruchniewicz, W. (2003). Horse riding academy. Equestrian Academy.

5. Pruski, W. (1982). The history of equestrian competitions in Poland. Sport and Tourism.

6. Pruski, W., Grabowski, J., Schuch, S. (1963). Horse breeding. State Agricultural and Forestry Publishers.

7. Urban, R. (2013). Equestrian sport in Poland between 1945 and 1989. Academy of physical education.

8. Wadowski, S., Wadowski, A. (1984). Horse riding principles for the agricultural university students. The University of Agriculture and Technology.

9. Wagner, R. (1986). The influence of horse riding schools on building of horse tack in Poland. National Scientific Publishing House.

10. Wójcik, Z. (2010). Equestrian sport in Warmia and Mazury regions in the years 1945-1975. ERZET.

11. Wójcik, Z. (2011). Leading schools and systems of horse riding in Europe (1550-1920). Academic Yearbooks of the College of Physical Education and Tourism, 102-104.

\section{Unreleased works}

12. Urban, R. (2003). Development of horse riding sport in Poland between years 1918 and 1939. Academy of Physical Education.

Стаття надійшла до редакції 06.12.2019 р. 